\title{
The Orientation of College Chinese Course in Vocational College Based on the Research of Learning Situation--Taking the college Chinese teaching for pre-school education major students as an example
}

\author{
Ling Zhang \\ School of Education, Yunnan Open University, Kunming, 650500, People's Republic of China \\ zhangling7412@163.com
}

Keywords: College Chinese, Research of Learning Situation, Course Orientation

\begin{abstract}
College Chinese is getting more and more attention, however the orientation of college Chinese course gets abundant of controversies, including utility-theory, aesthetic-theory, humanities-theory, culture-theory, and comprehensive-theory. All these theories sound reasonable, but what is the difference and relationship between them? Are the conclusions based on the research of learning situation? In this paper, based on comparative analysis, questionnaire survey of learning situation and interviews, and action research of practical teaching, it is presented that the orientation of college Chinese course in vocational college cannot be a pure theory hypothesis, but an effective comprehensive-theory of course orientation based on the research of learning situation.
\end{abstract}

\section{Nowadays research debate on the orientation of Chinese course in colleges has its own merits.}

The predecessor of college Chinese was the "freshman Chinese", which began in 1938, and was abolished after the college and department adjustment in the early period of New China; in the early 70 's, under the initiative of the former presidents, Kuang Yaming, Su Buqing and others, the colleges began to set up college Chinese course. Today, from the guidance of national policy to the actual implementation in colleges, college Chinese course is paid more and more attention, but at the same time there is debate of the course orientation.

There are five main arguments on the course orientation: utility-theory, aesthetic-theory, humanities-theory, culture-theory, and comprehensive-theory.

Utility-theory thinks that on the basis of middle school Chinese, college Chinese should further enhance the improvement of Chinese competences on listening, speaking, reading, and writing, emphasizing "To learn, To use "; many schools even equate the college Chinese with the practical writing, saying that the practical writing is more practical than the college Chinese. "The aim of the course is to develop the ability of reading, appreciating, understanding and expressing on Chinese linguistics and literature. "This is the orientation and expression of college Chinese education posted by the former state education commission."

Aesthetic-theory, can also be referred to literature-theory, thinks that the college Chinese must be the interpretation of literary classics, leading students into the aesthetic space of poetic emotion, improving students ' literary appreciation and aesthetic ability, also be distinguished from the cultivation of basic language ability in middle school age and the examination-oriented education. 
Humanities-theory believes that the essence of college Chinese should be the humanistic quality education. "Humanistic dimension is the highest goal of the college Chinese education in accordance with the basic task of "Educate People" in colleges.”[1]

Culture-theory considers that the college Chinese is the core course of inheriting Chinese excellent traditional culture. "' College Chinese ' and ' Chinese Culture Introduction ' are taught together with ideological and political theory courses, which stepwise constitutes basic courses group of the perfect Chinese outstanding traditional culture education." [2] Now in the decisive stage of building a moderately prosperous society and in the process of the great rejuvenation of the Chinese nation, the general secretary of China, Mr. Xi, stressed during the 19th National Congress of the Communist Party of China: "Culture is the soul of a nation. Culture prosperous, nation destiny prosperous too. Culture strong, nation strong too. Without a high degree of cultural self-confidence, without the flourishing prosperity of culture, there is no great rejuvenation of the Chinese nation. "The cultural heritage and innovation function of college Chinese is to play a role in the new era.

Comprehensive-theory thinks that function of the college Chinese is the combination of two or three of these four theories. "Fine reading of the text finally makes utility-theory and humanities-theory of Chinese education unified in classical texts." [3] "Aesthetic education is the basic way to build the humanistic dimension of the college Chinese education." [4] Professor Yang Shuzi, director of Cultural Quality Education Steering Committee of Education Ministry and an academician of the Chinese Academy of Sciences, said that "Humanistic culture has an important foundation." "The teaching objectives and course contents of the 'college Chinese' are located in the standard of inheriting the excellent traditional Chinese culture in college, and it accords with the actual properties of the 'college Chinese' as the mother tongue education course. The "college Chinese" should be a comprehensive humanistic quality education course, while the basic connotation of humanistic quality education is the excellent traditional Chinese culture education. [5] From the above viewpoint, it is known that the orientation of Chinese course in colleges is more of a comprehensive understanding.

\section{Introspection on Debate}

Each of these statements has its own reasons and requires, we need to identify the differences and connections between different viewpoints. At the same time, it is important to learn that through logical reasoning is important, only the approach of achieving the target based on the actual situation can be the fruitful, moderate and effective practice.

(1)Sorted Comparison of Comprehensive-theory

To sort the difference and connection between utility-theory, aesthetic-theory, humanities-theory, and culture-theory firstly, then comprehensive-theory can be regarded with a better view.

The tool function can be implemented in the humanities and culture education, both are compatible. The promotion of aesthetic ability can also be the process of humanities education, the aesthetic itself is the means of humane education, while the core of humanistic education is consistent with the core of Chinese excellent traditional culture, while its spirit essence is people-oriented. In other words, the tool and aesthetic natures of college Chinese are the means and approaches of college Chinese education, and the humanities and culture natures are the contents of college Chinese education. At the same time, the tool and aesthetic natures of college Chinese are the embodiment of ability goal, while humanities and culture natures are the embodiment of 
humanistic quality goal. The effect of college Chinese education should be synthetically evaluated from four perspectives of utility, aesthetic, humanities and culture.

The figure shows teaching activities of the college Chinese:

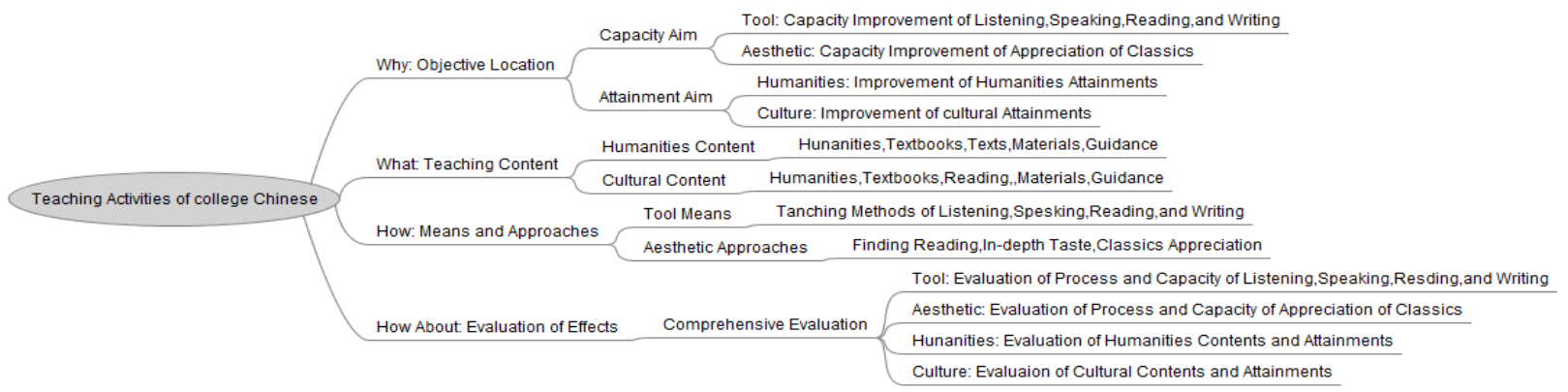

Fig. 1.Mind Map of College Chinese Teaching Activities

The above figure analyzes college Chinese teaching activities from four dimensions of the objective, content, process, evaluation; it shows clearly the difference and connection between utility-theory, aesthetic-theory, humanities-theory, and culture-theory; centering on college Chinese teaching activities, compositing the four theories, and the system relationship of what, why, how and how about is concluded.

(2) Discussion and Study of Comprehensive-theory Based on the Research of Learning Situation

This kind of comprehensive-theory built by logical reasoning, can it be implemented in practical operation? Can it withstand the test of practice? How far can the comprehensive depth be? Will it heavy the burden for students and teacher? Willit only be a good idea? Can it withstand the test of practice?

According to the constructivism learning theory, we need to understand the students ' actual learning basis and ability, follow the education rule of the nearest development area, so that the students ' study will be gradual and effective. According to the humanistic education learning theory, we need to pay attention to the emotional and affectional needs of students, fully mobilize the enthusiasm of students' study, and ensure students' real and effective participation, only in this way, teaching can take more responsibility, and lay a good foundation for students' the continuous learning and sustainable development.

To this end, teachers need to verify the practicality of comprehensive-theory through survey and practice. I design a questionnaire survey to investigate students ' subjective awareness and emotional and affectional tendencies, and exchange views with students through interviews. In the actual teaching, we should in-depth understand the students learning knowledge and ability base, and actively explore the appropriate teaching methods to motivate initiative of students' active study.

\section{Exploration of Research Program Design and Practical Teaching}

Two classes of students in the pre-school education major are selected as objects of surveying; Electronic questionnaire survey is applied on the internet, and the interviews launched on the online platform.

(1)The questionnaire survey is designed as follows:

In these questionnaires every topic has a single answer. The five options for each topic: very agreeable, agreeable, unknown, disagreeable and very disagreeable. From the four dimensions of 
utility, aesthetic, humanities and culture, questions are set up; 3 questions for the tool function, 1 question for the Chinese excellent traditional culture inheriting, 6 questions for the cultivation of humanities attainment, 1 question for aesthetic education; in addition, 3 questions for the relationship between college Chinese and students ' professional development,1 question for the receiving-type teaching method, 2 questions for the independent study, 9 questions for the cooperation study, 8 questions for the specialized Chinese study method. Altogether are 34 questions. Mainly are positive questions, a few reverse questions, some content repetitive questions, in order to test the reliability of the questionnaires.

(2) Interview Design:

(2.1)The class hour is too limited, the wish is too plump, one semester of college Chinese study, how to try hard, from which aspect to try better?

(2.2) Students have positive subjective desires of studying college Chinese, good opinions and suggestions in learning mode and method; however, the specific implementation seems much said and little done, the concrete action never keeps up with the subjective idea. Please rethink on what goes wrong and what are the specific reasons and difficulties?

(3) Observation and Perception of Specific Teaching:

In the specific teaching process, understanding about student's situation is obtained, namely, memorization basis, aesthetic ability, reading habits and quantity, thinking ability of students, oral and written expression ability, humanities knowledge, cultural foundation, etc.

\section{Data Investigation, Materials Collation and Analysis}

(1)Summary Analysis of Questionnaire Data:

98 pieces of questionnaires are released, 89 pieces are handed in. The recovery rate is $90.8 \%$. Questionnaire with reliability problems isn't found.

\subsection{Target Perspective}

From four target perspectives of utility, aesthetic, humanities and culture to observe students' the subjective wills, four functions should be needed by students, and it seems almost $90 \%$ of identity, more than $50 \%$ a strong desire. Therefore, the comprehensive course orientation is in line with the students ' subjective wishes. Specific data are shown in the following table:

Table 1.Achievingthe Humanistic Attainment Goal

\begin{tabular}{|l|l|l|l|l|l|}
\hline Questions & $\begin{array}{l}\text { Very } \\
\text { Agreeable }\end{array}$ & Agreeable & Unknown & Disagreeable & $\begin{array}{l}\text { Very } \\
\text { Disagreeable }\end{array}$ \\
\hline $\begin{array}{l}\text { To study college Chinese, I want to improve my } \\
\text { humanistic comprehensive quality. }\end{array}$ & 43.8 & 52.8 & 2.3 & 1.1 & 0 \\
\hline $\begin{array}{l}\text { To study college Chinese, I want to broaden my } \\
\text { humanistic horizons. }\end{array}$ & 41.6 & 53.9 & 3.4 & 0 & 1.1 \\
\hline $\begin{array}{l}\text { To study college Chinese, I want to exercise the } \\
\text { ability of independently thinking and judging, and } \\
\text { to develop habits. }\end{array}$ & 39.3 & 51.7 & 7.9 & 0 & 1.1 \\
\hline $\begin{array}{l}\text { To study college Chinese, I want to exercise the } \\
\text { ability of freely self-express, and to develop } \\
\text { habits. }\end{array}$ & 56.2 & 40.5 & 2.3 & 0 & 1.1 \\
\hline
\end{tabular}


Table 1. cont.

\begin{tabular}{|l|l|l|l|l|l|}
\hline $\begin{array}{l}\text { To study college Chinese, I want to be a person who loves } \\
\text { life and know how to love life. }\end{array}$ & 37.1 & 51.7 & 5.6 & 4.5 & 1.1 \\
\hline $\begin{array}{l}\text { To study college Chinese, I want to know how to respect } \\
\text { myself and others, how to love myself and others. }\end{array}$ & 41.6 & 53.9 & 3.4 & 1.1 & 0 \\
\hline
\end{tabular}

Table 2.Achieving the Cultural Inheritance Goal

\begin{tabular}{|l|l|l|l|l|l|}
\hline Question & $\begin{array}{l}\text { Very } \\
\text { Agreeable }\end{array}$ & Agreeable & Unknown & Disagreeable & Very Disagreeable \\
\hline $\begin{array}{l}\text { To study college Chinese, I } \\
\text { like to inherit Chinese } \\
\text { excellent traditional culture } \\
\text { better. }\end{array}$ & 61.8 & 32.6 & 4.5 & 0 & 1.1 \\
\hline
\end{tabular}

Table 3. Achieving the Literature Aesthetic Goal

\begin{tabular}{|l|l|l|l|l|l|}
\hline Question & $\begin{array}{l}\text { Very } \\
\text { Agreeable }\end{array}$ & Agreeable & Unknown & Disagreeable & $\begin{array}{l}\text { Very } \\
\text { Disagreeable }\end{array}$ \\
\hline $\begin{array}{l}\text { To study college Chinese, I want to } \\
\text { get the literature edification and the } \\
\text { feeling and experience of beauty. }\end{array}$ & 44.9 & 47.2 & 6.7 & 0 & 1.1 \\
\hline
\end{tabular}

Table 4. Achieving the Tool Function Objective

\begin{tabular}{|l|l|l|l|l|l|}
\hline Questions & $\begin{array}{l}\text { Very } \\
\text { Agreeable }\end{array}$ & Agreeable & Unknown & Disagreeable & $\begin{array}{l}\text { Very } \\
\text { Disagreeable }\end{array}$ \\
\hline $\begin{array}{l}\text { To study college Chinese, I want to talk } \\
\text { with eloquence in life. }\end{array}$ & 37.1 & 49.4 & 10.1 & 3.4 & 0 \\
\hline $\begin{array}{l}\text { To study college Chinese, I want to be } \\
\text { able to write leave notes, invitations, } \\
\text { reports, and summaries, etc. }\end{array}$ & 25.8 & 60.7 & 6.7 & 6.7 & 0 \\
\hline $\begin{array}{l}\text { To study college Chinese, I want to be a } \\
\text { person who is willing to write poems, } \\
\text { novels or proses. }\end{array}$ & 21.4 & 38.2 & 29.2 & 11.2 & 0 \\
\hline
\end{tabular}

\section{(1.2) Professional Development Perspective}

The majority of students in pre-school major think that the study of college Chinese is not useless to professional development, and $95.5 \%$ of students wish the study of college Chinese can be helpful to the professional development, very few students doubt that the college Chinese is useful to professional development. The high degree of identity of college Chinese may be related to the nature of pre-school education, because students in pre-school major are the future preschool teachers, the preschool teacher occupation itself requires students to have more comprehensive Chinese quality, including humanistic feelings and cultural attainment. It also shows that based on the research of practical learning situation, the orientation of college Chinese course in pre-school education major is suitable for the comprehensive-theory of course orientation. Specific data are shown in the following table: 
Table 5.Role of Professional Development

\begin{tabular}{|l|l|l|l|l|l|}
\hline Questions & $\begin{array}{l}\text { Very } \\
\text { Agreeable }\end{array}$ & Agreeable & Unknown & Disagreeable & $\begin{array}{l}\text { Very } \\
\text { Disagreeable }\end{array}$ \\
\hline $\begin{array}{l}\text { For non-Chinese major students, college } \\
\text { Chinese is a dispensable course. }\end{array}$ & 2.3 & 1.1 & 3.4 & 60.7 & 32.6 \\
\hline $\begin{array}{l}\text { To study college Chinese, I would like to get } \\
\text { help to the professional development of my } \\
\text { pre-school education major. }\end{array}$ & 48.3 & 47.2 & 3.4 & $1 \circ 1$ & 0 \\
\hline $\begin{array}{l}\text { To study college Chinese, there is little help to } \\
\text { the professional development of pre-school } \\
\text { major students. }\end{array}$ & 3.4 & 3.4 & 10.1 & 58.4 & 24.7 \\
\hline
\end{tabular}

\section{(1.3) Learning Method}

From the learning method, the vast majority of students agree to reception learning on one hand, but also like independent learning, cooperative learning, and activity learning, which are learning methods advocated by constructivism and humanism. It is clear that the teacher's brilliant interpretation is appreciated; at the same time, students are willing to construct knowledge and promote capacity independently. Teacher-led fine reading is very popular with students. Declamation is more popular than recitation. Panel discussion is more popular than individual expression in the class. On the web platform, more students publish opinion in real name than anonymously, while many people like both ways. The diversity of learning methods shows that the integrated course orientation function can be realized through the comprehensive of learning methods.

Table 6.ReceptiveLearning Method

\begin{tabular}{|l|c|c|c|c|c|}
\hline Question & $\begin{array}{l}\text { Very } \\
\text { Agreeable }\end{array}$ & Agreeable & Unknown & Disagreeable & $\begin{array}{l}\text { Very } \\
\text { Disagreeable }\end{array}$ \\
\hline $\begin{array}{l}\text { To study college Chinese, I like the way } \\
\text { of teachers talking, students listening. }\end{array}$ & 27 & 41.6 & 11.2 & 19.1 & 1.1 \\
\hline
\end{tabular}

Table 7. Autonomous Learning Method

\begin{tabular}{|l|l|l|l|l|l|}
\hline Questions & $\begin{array}{l}\text { Very } \\
\text { Agreeable }\end{array}$ & Agreeable & Unknown & Disagreeable & $\begin{array}{l}\text { Very } \\
\text { Disagreeable }\end{array}$ \\
\hline $\begin{array}{l}\text { To study college Chinese, I like the way } \\
\text { teachers helping and urging me to study } \\
\text { autonomously. }\end{array}$ & 16.9 & 51.7 & 12.4 & 19.1 & 0 \\
\hline $\begin{array}{l}\text { To study College Chinese, I like to apply } \\
\text { mobile phone, network and other } \\
\text { information means to self-study. }\end{array}$ & 16.9 & 61.8 & 5.6 & 15.7 & 0 \\
\hline
\end{tabular}


Table 8. Cooperative Learning Method

\begin{tabular}{|l|l|l|l|l|l|}
\hline Questions & $\begin{array}{l}\text { Very } \\
\text { Agreeable }\end{array}$ & Agreeable & Unknown & Disagreeable & $\begin{array}{l}\text { Very } \\
\text { Disagreeable }\end{array}$ \\
\hline $\begin{array}{l}\text { To study college Chinese, I like group } \\
\text { discussion. }\end{array}$ & 29.2 & 61.8 & 7.9 & 1.1 & 0 \\
\hline $\begin{array}{l}\text { To study college Chinese, I like group } \\
\text { collaboration. }\end{array}$ & 32.6 & 61.8 & 4.5 & 1.1 & 0 \\
\hline $\begin{array}{l}\text { To study college Chinese, I like group } \\
\text { collaboration, because it is fun and easy. }\end{array}$ & 16.9 & 39.8 & 9 & 31.5 & 3.4 \\
\hline $\begin{array}{l}\text { To study college Chinese, I like group } \\
\text { collaboration, because of high participation, } \\
\text { high efficiency and great harvest. }\end{array}$ & 41.6 & 50.6 & 3.4 & 4.5 & 0 \\
\hline $\begin{array}{l}\text { To study college Chinese, I prefer to express } \\
\text { my views in the group. }\end{array}$ & 19.1 & 59.6 & 14.6 & 6.7 & 0 \\
\hline $\begin{array}{l}\text { To study college Chinese, I prefer to express } \\
\text { my opinion in the whole class. }\end{array}$ & 13.5 & 27 & 44.9 & 14.6 & 0 \\
\hline $\begin{array}{l}\text { To study college Chinese, I prefer not to } \\
\text { express my opinion, but to listen to others. }\end{array}$ & 7.9 & 12.4 & 18 & 50.6 & 11.2 \\
\hline $\begin{array}{l}\text { To study college Chinese, I prefer to express } \\
\text { my opinion anonymously on the class network. }\end{array}$ & 7.9 & 29.2 & 20.2 & 38.2 & 4.5 \\
\hline $\begin{array}{l}\text { To study college Chinese, I prefer to express } \\
\text { my opinion in real name on the class network. }\end{array}$ & 10.1 & 42.7 & 37.1 & 9 & 1.1 \\
\hline
\end{tabular}

Table 9. Learning Methods of Chinese Activities

\begin{tabular}{|l|l|l|l|l|l|}
\hline Questions & $\begin{array}{l}\text { Very } \\
\text { Agreeable }\end{array}$ & Agreeable & Unknown & Disagreeable & $\begin{array}{l}\text { Very } \\
\text { Disagreeable }\end{array}$ \\
\hline $\begin{array}{l}\text { 28. To study college Chinese, I like } \\
\text { declamation learning method. }\end{array}$ & 19.1 & 58.4 & 11.2 & 11.2 & 0 \\
\hline $\begin{array}{l}\text { 29. To study college Chinese, I like } \\
\text { recitation learning method. }\end{array}$ & 4.5 & 34.8 & 18 & 40.5 & 2.3 \\
\hline $\begin{array}{l}\text { 30. To study college Chinese, I like } \\
\text { the learning methods of in-depth } \\
\text { study, fine reading. }\end{array}$ & 16.9 & 56.2 & 18 & 9 & 0 \\
\hline $\begin{array}{l}\text { 31. To study College Chinese, I like } \\
\text { the learning method of speech. }\end{array}$ & 16.9 & 32.6 & 28.1 & 22.5 & 0 \\
\hline $\begin{array}{l}\text { 32. To study College Chinese, I like } \\
\text { learning methods of debate } \\
\text { competition. }\end{array}$ & 13.5 & 43.8 & 15.7 & 25.8 & 1.1 \\
\hline $\begin{array}{l}\text { 33. To study College Chinese, I like } \\
\text { the learning method of role-playing. }\end{array}$ & 20.2 & 55.1 & 13.5 & 10.1 & 1.1 \\
\hline $\begin{array}{l}\text { 34. To study College Chinese, I like } \\
\text { learning method of creative } \\
\text { composing. }\end{array}$ & 15.7 & 50.6 & 27 & 6.7 & 0 \\
\hline $\begin{array}{l}\text { 35. To study College Chinese, I like } \\
\text { to organize the learning methods of } \\
\text { lively and diverse activities. }\end{array}$ & 32.6 & 57.3 & 7.9 & 2.3 & 0 \\
\hline
\end{tabular}


This questionnaire is organized after students received after 8 class hours of college Chinese teaching; in the process of teaching subtle influence on students may happen. If the questionnaire is organized at the start of the semester, the data may not show so impressive inclination. But it does not affect our analysis of the orientation of college Chinese course, on the contrary, the teaching strategies adopted by teachers have gained remarkable results.

(2) Interview Results:

(2.1)The question "The class hour is too limited, the wish is too plump, the one semester of college Chinese study, how to try hard, from which aspect to try better?

"Students put forward a solution with foresight.

72students out of 81 answered, and many of the students ' answers are insightful. For example: Yang Yuli says: "We need to first of all to cultivate the interest in college Chinese learning, secondly to master the learning method and focus, and to recite some famous poems. Chinese literature has long history. Poetry selected in textbooks are masterpieces, combining both ideological and artistic features; reciting of them is a kind of enjoyment. "

The views of answers are summed up in the following points:

(a) The first thing is to cultivate interest in learning, and enjoy college Chinese study, enthusiasm is the best motivation.

(b) It is mainly relies on independent, after class, timely, and lifelong study, and learning with partners.

(c) It is needed to combine the Chinese content with life, to observe the details in life, Chinese is everywhere in life.

(d) It is needed to master learning methods and focus, take a variety of methods to learn, such as activities, organizing associations, in-depth study, on the library, warm so know new, preview and review combination.

(2.2)The question " Students have positive subjective desire of studying college Chinese, good opinions and suggestions in learning mode and method; however, the specific implementation seems much said and little done, the concrete action never keeps up with the subjective idea. Please rethink on what goes wrong and what are the specific reasons and difficulties? ”

The summarized views are: 40students out of 81 answered. For example, Li Ying replies: "As a commissary in charge of study in class, I have not played a leading and organizational role."

(a) Cooperative learning organization is not mature and in place.

(b) Self-learning ability is limited.

(c) The use of time after class is unscientific.

(d) Reactions of students 'knowledge and behavior reflect differently.

(e) Some students are too reserved.

From the interview result, students' answers are highly consistent with the questionnaire data, these students not only have subjectively strong intention of comprehensive course function, but also recognition of the method for realizing the comprehensive course function.

(3) Actual Teaching Observation and Experience

Teachers adopt the receptive way of knowledge teaching, the classical interpretation of aesthetic appreciation, and also declamation, recitation and other activity teaching methods, to organize and guide students to study independently and cooperatively. Students like the excellent teaching of teachers, and teacher-led fine reading can play a good demonstration role for students. Some students show a strong self-learning ability, all students have a great deal of self-learning potential. 
Students can understand the literal meaning of ancient prose by network learning means. Students ' dialectical, independent, aesthetic and creative thinking are generally passable and further development is needed. Students want a depth of creative guidance from teachers. Teachers' lecture teachings preempt too much class hour and mistakes in depriving students' independent study right happen likely.

\section{Conclusions}

In this paper, theoretical analysis of the arguments about the orientation of college Chinese course, comparing of their differences and analysis of their relationship are carried out, the systematic relation of comprehensive theory of the orientation of college Chinese course is found out: Taking the college Chinese teaching activity as the core, synthesizing four theories, forming the comprehensive relationship of goal, content, process and effect evaluation.

According to questionnaire survey and interview investigation on learning situation, the comprehensive requirements of pre-school education major students' college Chinese learning objectives, learning methods and course orientation are aware of. At the same time, the synthesis of learning methods is the way to realize the comprehensive function of the course.

Through analysis of the actual teaching process and effect of the college Chinese for pre-school education major students, it is found out that although the teaching time is not long, various teaching methods in college Chinese teaching are welcomed by students and have played a good teaching effect.

In brief, the orientation of Chinese course in vocational colleges should be a comprehensive course orientation, and corresponding course teaching strategies are needed to realize its comprehensive function.

\section{References}

[1] Zhao Jingli. The Humanistic Dimension of Reconstructing the College Chinese Education [J], Modern College Education, 2010 (1): 93-99

[2] Guo Haijun, Zhang Xudong. Chinese Excellent Traditional Culture Education and College Chinese Course Construction [J], Normal Journal (Philosophy and Social Sciences Edition), 2015 (2): 181-184

[3] Qin Chaohui, Sun Li. A Study on the Teaching Model of "Three Levels" in the Fine Reading of Classic Text of College Chinese (J), Chinese college Teaching, 2014 (4): 63-66

[4] Zhao Jingli. The Humanistic Dimension of Reconstructing the College Chinese Education [J], Modern College Education, 2010 (1): 93-99

[5] Guo Haijun, Zhang Xudong. Chinese Excellent Traditional Culture Education and College Chinese Course Construction [J], Normal Journal (Philosophy and Social Sciences Edition), 2015 (2): 181-184 